\title{
Consumer Perceptions of Sate Bandeng Attributes
}

\author{
*Meutia \\ Department of Agribusiness \\ University of Sultan Ageng Tirtayasa \\ Serang,Banten 42122, Indonesia \\ *Tia_almer@yahoo.co.id
}

\author{
Tubagus Ismail \\ Department of Accounting \\ University of Sultan Ageng Tirtayasa \\ Serang,Banten 42122, Indonesia \\ adeismail73@gmail.com
}

\author{
Ahmad Bukhori \\ Department of Agribusiness \\ University of Sultan Ageng Tirtayasa \\ Serang,Banten 42122, Indonesia
}

\begin{abstract}
One of the potential processed fishes that characterizes Banten souvenirs is sate bandeng. The purpose of this study was to analyze consumer perceptions of various attributes of sate bandeng as a typical gift from Banten Province. The number of respondents taken were 150 people by organoleptic tests on 7 products of sate bandeng SMEs from Serang City, Serang Regency and Cilegon City which were carried out in Serang City. The method used is quantitative descriptive method. Sampling using nonprobability sampling with sampling techniques with accidental sampling. The research method with survey method is by distributing questionnaires to respondents then identifying consumer perceptions of the attributes of sate bandeng through organoleptic tests. The results show that taste, price, aroma, color and packaging have different choices by consumers. The taste, price, and aroma attributes of consumers choose Hasnah's UKM. For the colors of consumers choosing SMEs owned by packaging consumers prefer Aliyah's SMEs. This research can be used as a basis for SMEs in prioritizing what attributes are most preferred by consumers and for consumers can be used as a reference in selecting various sate bandeng products in Banten Province.
\end{abstract}

\section{Keywords: Land, Sustainable Food Security, Islamic}

\section{INTRODUCTION}

Milkfish is one of the fisheries potential in Banten Province. Geographically Banten is located on the tip of the island of Java which has a long coastline which is mostly used for ponds. One of them is milkfish ponds. Besides its potential, milkfish also has the disadvantage of milkfish that smells of mud and thorns that are not easy to clean. This causes milkfish to be less practical for consumption, especially by children and the elderly. For this reason, an effort is needed to deal with the use of milkfish, one of which is processing milkfish into products that have added value so that they can overcome such problems as sate bandeng.

Sate bandeng is one of the processed milkfish products. Sate bandeng processing business is categorized into agroindustry and most of these businesses are carried out in the scale of small and medium-sized businesses which are classified into home industries. The existence of sate bandeng business has existed since the time of the Banten sultanate (Ismail et al., 218). Many SMEs produce sate bandeng, especially Serang, Serang and Cilegon. Along the way can easily be found sate bandeng because it has become a souvenir icon of Banten (Meutia et al., 2018).

Sate bandeng has many flavors such as savory, sweet, salty and spicy. The way of making it is also diverse, some are steamed and some are burned. Likewise, the spices used are those that use coconut milk and some are not. Seasonings and manufacturing processes determine the quality and durability of sate bandeng (Meutia et al., 2017). The form of packaging is also diverse, some are wrapped in leaves, some are directly burned, some are using plastic packaging. The process of making sate bandeng depends on the origin of the area. In the study there were three locations taken, namely Serang Regency, Serang City and Cilegon City. This study will further analyze consumer perceptions in choosing sate bandeng by comparing various attributes including price, taste, aroma, color and packaging.

\section{LITERATURE REVIEW}

\section{A. Processed Sate Bandeng Local Food Products}

Local food processing products are processed food products made from local resources processed and managed by home industries and MSEs. The abundant potential of local resources in Banten province is a huge potential for SME development. Until now the existence of local food processed products in Banten Province is still not exposed compared to other local food processed products from the province in Java. Even though quality and taste are not inferior compared to other provinces' local food products (Meutia et al., 2018).

One product that is very potential to be developed is processed fish. Fish is a potential animal source, so it takes effort to increase endurance through preservation and processing of various processed fish products for maximum utilization. One of the most well-known milkfish processing in Banten Province is sate banfdeng which according to history is 
the king's favorite food (Meutia et al., 2017). Milkfish is processed into sate bandeng because milkfish has a lot of bones so that it is easy to consume sate bandeng which has been separated from thorns. Sate bandeng is processed milkfish which has been separated by thorns and added a few other spices then stabbed in bamboo like satay and then grilled or steamed. Sate bandeng is found in many shops by those around Serang City and in Serang District (Meutia, 2018).

Sate bandeng is one of the diversified products of milkfish produced by the Serang community. In general, processing of sate bandeng production is in the form of home / small industries carried out in people's homes using simple and traditional equipment. As a typical product, it is certainly not difficult to find sate bandeng products in the City and Serang Regencies (Suherna et al, 2014)

Sate bandeng is a protein-based local food processing. Weakness of milkfish has milkfish that smells of mud and thorns that are not easy to clean. This causes milkfish to be less practical for consumption, especially by children and the elderly. For this reason, an effort is needed to deal with the use of milkfish, one of which is processing milkfish into products that have added value so that they can overcome these problems. Sate bandeng is a semi-wet product that is quickly damaged and has a shelf life of around 3 days so that the marketing range of this product is still in the area of Banten, Jakarta and West Java. Sate bandeng is one of the processed milkfish products. Sate bandeng processing business is categorized into agro-industry and most of these businesses are carried out in the scale of small and medium-sized businesses which are classified into home industries.

B. Consumer Attributes and Perceptions

Perception is a process that arises due to sensation, where the notion of sensation is the activity of feeling or causing an emotional state of joy. Sensation can also be defined as a quick response from our recipient senses to basic stimuli such as light, color, and sound. With that in mind, perception will arise. The definition of perception is the process of how stimuli are selected, organized, and interpreted (Nugroho, 2003). Ristiyanti (2005) states that sensations come and receive by humans through the five senses. Some sensations through the five senses that affect consumer perceptions:

1. Vision, Marketers control consumers' visual functions in almost all marketing tips. Various advertising products are used, product packaging, very attention to the effects of color, light, style, layout, size and so on. All are intended to provide stimulation to consumers' eyesight.

2. Odor or smell, certain odors or aromas can affect a person's emotions, reminding of the past reducing stress. Like color, smell also creates sensations related to culture or something that is learned.

3. Sound or Sound, Music has proven to provide its own strength in human life. Marketing communication to influence consumers, especially in moods, music plays an important role.
4. Feel, consumers feel a product sample of fabric and associate the touch with the quality of fabric products.

5. Taste, Essential taste for food and medicine products, consumer tastes in terms of taste are different. In line with efforts to differentiate food producers, the tastes of foreign countries become interesting objects.

Product attributes are all features (both tangible and intangible) of an item or service that can be valued by customers (Lovelock and Wright, 2007). According to Simamora (2004) revealed there are two meanings that can be given if an object is a product category. First, attributes as characteristics that can distinguish one product from another. Second, the factors that consumers consider in making decisions about purchasing a product category, which is attached to the product or being part of the product itself. Product attributes consist of three types, namely (1) features which are the size, characteristics of product attributes (taste, color, aroma), appearance, price, service, composition, ethical values, colors and others, (2) benefit that is the use or pleasure associated with the five senses or can also be a manifested benefit, (3) a function in the form of characteristics or benefits.

\section{METHODOLOGY}

The method used in this research is survey method. Survey Method is a method that uses questionnaires to collect data in the field. The questionnaire used for this study was distributed to several consumers. In addition to distributing questionnaires, researchers will also conduct interviews. The location of the research was conducted in Serang town square by taking samples of sate bandeng from 7 craftsmen in Serang City, Serang District and Cilegon City. The time of this research was held from July to August 2018. The types and sources of data used in this study were primary data and secondary data. Primary data is the main data in this study which was obtained directly from respondents through interviews using a prepared questionnaire. Secondary data is supporting data for this study which is recorded systematically or cited directly from the relevant institutions in this study. The method of determining the sample of respondents used in this study is non-probability sampling, with the accidental sampling method. Respondents who were declared suitable as data sources, were respondents who had consumed the seven sate bandeng that were examined. The attributes of sate bandeng are the characteristics or characteristics inherent in the sate bandeng, namely (1) taste is the sensory response to nerve stimuli such as very tasty, tasty, ordinary, unpleasant, and very unpleasant. (2) Price is an exchange rate that can be equated with money for benefits derived from an item or service. (3) Aroma is a value contained in a product that can be directly enjoyed by consumers and provides an opinion based on the experience of consuming sate bandeng. (4) Color is a value contained in the product to determine the maturity level of the sate bandeng. (5) Packaging is a characteristic of 
the product that consumers can enjoy as a form of external appearance that packs a product. Data analysis using Multidimensional Scaling (MDS) is a technique that helps researchers to identify the main dimensions underlying respondents in evaluating certain objects

\section{DISCUSSION}

Satay is one of the most popular foods in Indonesia, served everywhere, from street vendors to luxury restaurants in hotels. Almost everyone knows satay. Satay is food made from the main ingredient in the form of meat which is cut into small pieces which are then pierced using bamboo which has been thinly cut. After the satay is stabbed, then burned using charcoal and seasoned. In Indonesia, satay is usually served with rice or rice cake. Sate bandeng is one of the processed products that use milkfish as the main raw material and this product is widely known by the wider community as a typical food of Banten region. The process of making sate bandeng is that milkfish that has been cleaned and then gently loosened by beating slowly. Next, the bone near the tail and head is severed and pulled carefully from the front. After that, the remaining meat and thorns are removed by squeezing from back to front. Then mixed with spices and then put again into the milkfish skin then steamed or burned.

Historically sate bandeng was introduced by Banten royal cooks for royal guests, meaning that milkfish processed is easily enjoyed because milkfish has many bone characteristics. Finally, milkfish is processed into satay in a unique way by separating between bone and meat and then being processed. The skill of making sate bandeng is only possessed by people who attack, with the descendants of royal cooks scattered around Lontar, Kaloran, Kaujon which are not far from the town square of Serang.

\section{A. Characteristics of Respondents}

The characteristics of respondents in this study determine the final result of the respondent's answers so that it will influence the results of the analysis. The description of the characteristics of respondents seen from the general characteristics is illustrated by variables such as gender, age, level of education, and employment.

Table 1. Characteristics of Respondents by Gender and Age

\begin{tabular}{lcc}
\multicolumn{1}{c}{ Gender } & Frek. & $\%$ \\
\hline Ladies & 95 & 63,33 \\
Gentleman & 55 & 36,67 \\
\hline Sum & 150 & 100 \\
\hline Age & Frek & $\%$ \\
\hline $17-23$ & 22 & 14,67 \\
\hline $24-30$ & 52 & 34.67 \\
\hline $31-40$ & 57 & 38 \\
\hline
\end{tabular}

\begin{tabular}{ccc}
\hline $41-50$ & 15 & 10 \\
\hline$>50$ & 4 & 2,66 \\
\hline Sum & 150 & 100 \\
\hline
\end{tabular}

Based on Table 1 above it can be seen that the respondents were dominated by women by $63.33 \%$ and men by $36.67 \%$. This is because most decision makers in choosing products are dominated by women. Based on the average age of respondents who buy typical local products is the productive age between the ages of 17 years to 40 years. This is because the research location of the Serang City square is a place of sports and entertainment.

The last level of education of respondents was categorized into several, namely elementary, junior high, high school, diploma, undergraduate and post graduate. Of the several categories, the most dominant are high schools, namely $40 \%$ and undergraduate $20 \%$.

Table 2. Distribution of Amounts and Percentages of Respondents Based on Education Levels and Job

\begin{tabular}{lclc}
\hline \multicolumn{1}{c}{ Education } & $\begin{array}{c}\text { Quan } \\
\text { tity }\end{array}$ & \multicolumn{1}{c}{ Job } & Total \\
\hline Elementry school & 2 & Housewife & 45 \\
Junior high school & 7 & Civil servant & 38 \\
Senior high school & 62 & $\begin{array}{l}\text { Private } \\
\text { employees }\end{array}$ & 35 \\
Diploma & 30 & Entrepreneur & 7 \\
Bachelor & 39 & Student & 21 \\
Postgraduate & 10 & Other & 4 \\
\hline \multicolumn{1}{c}{ Total } & 150 & \multicolumn{2}{c}{ Total } \\
\hline
\end{tabular}

Based on the type of work, most respondents as housewives and employees and civil servants. Most people buy for their own consumption or for salvation and some for souvenirs.

\section{B. Selection of Sate bandeng Attributes}

Perception is a process that arises due to sensation, where the notion of sensation is the activity of feeling or causing an emotional state of joy. Sensation can also be defined as a quick response from our recipient senses to basic stimuli such as light, color, and sound. With that in mind, perception will arise. The definition of perception is the process of how stimuli are selected, organized, and interpreted (Nugroho, 2003). This analysis is used to determine respondents' perceptions of the attributes of sate bandeng. This study uses attribute-based Perceptual Map analysis. The attributes used in this study are taste, price, aroma, color and packaging.

In the perception map in the picture the results of the study as a whole is the result of consumer perception. The formation of this position map is viewed from the perspective of the consumer as the person who consumes. Viewed from the consumer's point of view, consumers can consider which sate bandeng product is the most suitable for the gift of souvenirs. 
However, this perception map will be different when viewed from the perspective of the perception of sate bandeng entrepreneurs. If viewed from the point of view of the entrepreneur, this analysis will be very beneficial for producers in considering which strategy is most suitable to be applied to develop the business of sate bandeng.

\section{Multidimensional Scaling Analysis}

Multidimensional Scaling Analysis (MDS) is an analytical tool to find out how well the position map is displayed can be seen from the RSQ value and the stress obtained. Stress value, 0,31450 where the model is in the poor category, while RSQ is greater than 0,60 that is 0,64920 getting closer to 1 meaning that the data is mapped perfectly. Based on the RSQ perceptual maping, the image is considered feasible, meaning that the multidimensional scaling model has been effective against the suitability of data input. This analysis is used to find out the perceptions of respondents to Sate bandeng, so in this study an attribute-based perceptual map is used. The attributes used in this study are taste, price, aroma, color and packaging. In the perception map in the picture, overall shows the results of consumer perception. The formation of this position map is reviewed from the consumer's perspective.

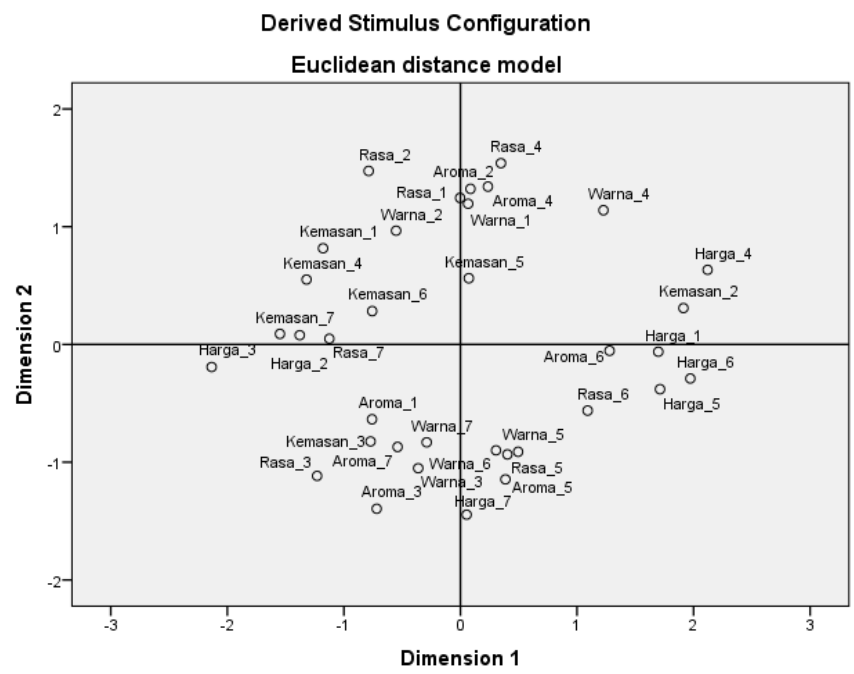

Figure 1. Perceptual Map resulting from Multidimensional Scalling of Sate bandeng Products

Remarks: Number 1 is SME from Serang City 1, Number 2 SMEs from Serang District 1, Number 3 SMEs from Serang District 2, Number 4 SMEs from Serang City 2, Number 5 SMEs in Cilegon City 1, Number 6 is Cilegon City 2 SMEs and Number 7 Cilegon City SMEs 3.

Based on Figure 4, there are 4 quadrants with different distribution of attributes that shows the relationship between attributes. The points adjacent to or located in the same quadrant indicate that the attribute is considered the same by the respondent. The purpose of the attribute that is considered the same by the respondent is the attributes that are questioned by the respondent. Quadrants that have positive values such as quadrant II, in contrast to quadrants that have negative values such as quadrant IV, while for quadrant sizes that have positive and negative values such as quadrant I and quadrant III. From these images from each quadrant and attributes can be explained as follows:

From the results of the Multidimensional Scaling analysis, on the taste attribute, the respondents considered the number 4 SME satay milkfish, number 3 sate bandeng and number 6 sate bandeng were considered superior because they were in the positive quadrants II and IV. Whereas sate bandeng number 1 and sate bandeng number 2 are in quadrant I which has positive negative value and sate bandeng number 5 and sate bandeng number 6 are in quadrant III which has negative positive value. From the results of this analysis, number 4 sate bandeng, number 3 sate bandeng and number 7 sate bandeng are considered very tasty and recommended compared to other sate bandeng.

In the price attribute, respondents rated number 1 sate bandeng, number 4 sate bandeng, number 2 sate bandeng and number 3 sate bandeng considered superior because they were in the positive quadrant and responded fairly well by consumers. Whereas sate bandeng number 5 and sate bandeng number 7 are in quadrant III which is negative positive. Consumers still consider the attributes of taste and price in choosing sate bandeng. The consumer aroma attribute assessed the number 1 satay milkfish, number 2 sate bandeng, number 3 sate bandeng, number 4 bandeng satay and number 7 sate bandeng considered to be superior and flavorful and considered positive by consumers compared to other satay products. In the color attribute, respondents rated number 1 sate bandeng, number 4 sate bandeng, number 6 sate bandeng and number 7 sate bandeng superior and interesting compared to others. This is because this badeng satay has also been packaged in a more attractive form. In the packaging attributes, respondents rated number 2 sate bandeng and number 3 sate bandeng which are superior and attractive compared to other types.

Of all the attributes tested, number 3 sate bandeng and milkfish 4 satay have many advantages and are positively valued by consumers. Each UKM comes from Serang City and Serang Regency. Packaging is not too decisive in making purchasing decisions for sate bandeng because some consumers actually expect natural packaging, namely banana leaf packaging. The disadvantage is that packaging from banana leaves causes sate bandeng to be long-lasting and easily contaminated by bacteria.

\section{CONCLUSION}

Overall, it can be concluded from all the attributes tested, that number 3 sate bandeng and milkfish 4 satay have many advantages and are positively valued by consumers. The 
consumer does not really worry about the color of the aroma and packaging because it is not a priority in their assessment. Packaging is not too decisive in making purchasing decisions for sate bandeng because some consumers actually expect natural packaging, namely banana leaf packaging. The disadvantage is that packaging from banana leaves causes sate bandeng to be long-lasting and easily contaminated by bacteria. In view of the taste attributes of sate bandeng SMEs from Serang City and Serang Regency are recommendations in making decisions in buying sate bandeng. Sate bandeng producers should maintain a distinctive flavor because this is an important attribute that consumers consider in choosing sate bandeng.

\section{REFERENCES}

[1] Lovelock, C \& Lauren K Wright. (2007). Services Marketing Management, PT. Index, Indonesia.

[2] Ismail, T. Meutia. Bukhori, A. Fajri, E. (2018). Building Innovation Capability Through the Triple Helix Model of Sinergy Improving SME's Marketing Performance. International Journal of Civil Engineering and Technology. Vol. 9 (7). Pp. 1403-1412

[3] Meutia, Ismail T, Bukhari. A (2018). Decision and Level of Consumer Satisfaction in Choosing Various Sate bandeng in Banten Province. Proceedings of the National Seminar on the 2018 Indonesian Higher Education Communication Forum (FKPTPI) Seminar and Workshop with the theme "Agriculture in the Innovation and Technology Acceleration to Realize Resource-Based Food Sovereignty and Local Wisdom", on 2 to 3 October 2018

[4] Meutia, Ismail Tubagus, Bukhari, Ahmad, (2017), Building Innovative Capabilities through the Synergy of Triple Helix Models to Improve Marketing Performance of Sate bandeng SMEs in Banten Province. Grant Research Proposal.

[5] Meutia, Tubagus Ismail, Ahmad Bukhari (2017). Identification of Diversity and Strategy for the Development of Local Food Processed Products in Banten Province, Proceedings of the National Conference of Western Region BKSPTN 2017. University of Bitung Belitung

[6] Nugroho, N.S. (2003). Consumer Behavior: Concepts and Implications for Marketing Strategy and Research, Jakarta, Predana Media

[7] Ristiyanti Prasetijo. (2005). Consumer behavior. Yogyakarta: Andi.

[8] Simamora, B. (2004). Guide to Consumer Behavior Research. Gramedia Main Library. Jakarta.

[9] Suherna, Sri Mulyati, Weksi Budiaji, Asih Mulyaningsih, Meutia. (2014). Consumer and Producer Perceptions of
Milk Sate Product Attributes. Proceedings of the Untirta National Seminar 